\title{
Research on image perception of Guilin tourism destination based on network text analysis
}

\author{
Rongfang Liang ${ }^{1, *}$, Shengfeng Luo ${ }^{1}$ \\ ${ }^{1}$ College of Tourism\&Landscape Architecture, Guilin University of Technology, Guilin 541000, China
}

\begin{abstract}
This article taking the travel notes of the ant mafengwo.com and Ctrip.com as a sample, using the content analysis method and ROST CM6 to analyze the visitors' perception of the Guilin tourism destination image, through the analysis of the high-frequency vocabulary and the semantics of the network notes, and the spindle coding, From eight categories of humanistic attraction, natural attraction, tourism transportation, special food, accommodation conditions, overall impression, tourism consumption and service level, It is found that the tourists' perception of Guilin tends to be positive. The basic information characteristics, cognitive image, emotional image and willingness to travel are comprehensively explored. The image of Guilin is proposed from the improvement of hardware elements, the innovation of tourism image marketing methods and the improvement of software image elements.
\end{abstract}

The perception image of tourism consumers on ${ }^{1}$ tourism destinations largely affects the choice of tourists for various tourism activities. Scientifically, consciously and accurately analyze the tourists' perception of tourism destinations, adopt various marketing methods, understand and meet the needs of tourists, to better promote the sustainable and healthy development of tourism destinations. The image of a tourist destination usually refers to the overall understanding, evaluation and impression of a tourist destination or potential tourist on a tourist destination. The choice of tourist destinations for potential travel consumers is largely influenced by the perception of the destination image ${ }^{[1]}$. Along with the rapid development of the Internet and the advent of the era of big data, a large number of tourism-related information on the network platform provides resources for tourismrelated research. In addition to the limitations of the questionnaires that may be induced and disturbed by tourists, the network information can fully reflect the tourists' perception of the image of the tourist destination.

\section{Research design}

This article uses the "Travel Notes" of ant mafengwo.com and Ctrip.com as the data source. The selection conditions are as follows: First, the time span is from January 1, 2018 to December 31, 2018; s Secondly, travel notes with more than 500 hits and more than 10 replies; Thirdly, Guilin is the main tourist route. A total of 200 eligible travel notes and 1 million words were selected after screening. This article use content analysis, which converts text on the media, valuabl non-quantitative information into quantifiable data, and establishes meaningful category decomposition information ${ }^{[2]}$. The selected 200 online travel notes were coded in an open way, and word frequency analysis was conducted with the help of ROST CM6 as an open coding tool. The more words appear, the higher the tourists' perception and consensus, which is the core of cognitive image. After open coding, the concept is coded in principal axis.

\section{Data analysis}

\subsection{Analysis of the basic characteristics of tourists}

The specific arrangements of tourists during the tour guide to some extent their personal perception of the image of the destination, through the analysis of the text, from the source of the place, travel mode, travel time, stay days, etc. Visitor information, each sample will be reflected to varying degrees, through the compilation of 200 samples, the results are shown in Table 1:

Table 1. Basic characteristics of tourists

\begin{tabular}{|c|c|c|}
\hline $\begin{array}{c}\text { Basic } \\
\text { characteristics of } \\
\text { tourists }\end{array}$ & Feature category & $\begin{array}{c}\text { Freque } \\
\text { ncy }\end{array}$ \\
\hline \multirow{4}{*}{ source area } & Shagnhai & 40 \\
\cline { 2 - 3 } & Hefei & 4 \\
\cline { 2 - 3 } & Guangzhou & 36 \\
\cline { 2 - 3 } & Beijing & 20 \\
\cline { 2 - 3 } & Guagnxi & 100 \\
\hline
\end{tabular}

\footnotetext{
* Corresponding author: 982809522@qq.com
} 


\begin{tabular}{|c|c|c|}
\hline \multirow{4}{*}{ travel mode } & Self-driving & 14 \\
\cline { 2 - 3 } & High-speed rail & 140 \\
\cline { 2 - 3 } & aircraft & 46 \\
\hline \multirow{4}{*}{ travel time } & December-February & 20 \\
\cline { 2 - 3 } & March-March & 50 \\
\cline { 2 - 3 } & June-August & 110 \\
\cline { 2 - 3 } & September- & 20 \\
\hline \multirow{7}{*}{ stay days } & November & \\
\cline { 2 - 3 } & 2-3 days & 46 \\
\cline { 2 - 3 } & 4-5 days & 110 \\
\hline \multirow{2}{*}{ 6-7 days } & 44 \\
\hline
\end{tabular}

Judging from the source of tourists, it can be concluded from the 200 travel notes collected. Guangxi has the largest proportion, and tourists choose high-speed rail as the first choice for their travel. Visitors to Guilin during the summer vacation account for the majority. The ratio is $55 \%$, and the proportion of staying days is about $55 \%$ from 4 to 5 days. The basic residence time is mainly short-term stay.

\subsection{Spindle coding}

Through the spindle coding of the top 100 high-frequency vocabulary appearing in the travel notes, the attributes and connotations of Guilin's tourism image can be obtained. As shown in table 2:

Table 2. 100 high frequency vocabulary spindle coding

\begin{tabular}{|c|c|c|}
\hline $\begin{array}{c}\text { Key } \\
\text { words }\end{array}$ & $\begin{array}{l}\text { Spindle } \\
\text { coding }\end{array}$ & Code interpretation \\
\hline $\begin{array}{c}\text { Solar and } \\
\text { Lunar } \\
\text { towers } \\
\text { Grand } \\
\text { Falls } \\
\text { Hotel, } \\
\text { East West } \\
\text { Street }\end{array}$ & $\begin{array}{c}\text { Human } \\
\text { attraction }\end{array}$ & $\begin{array}{l}\text { The unnatural causes } \\
\text { mentioned in the online } \\
\text { travels are mainly } \\
\text { tourist attractions } \\
\text { formed by artificial } \\
\text { influence. }\end{array}$ \\
\hline $\begin{array}{c}\text { Lijiang } \\
\text { river, } \\
\text { Elephant } \\
\text { Trunk Hill }\end{array}$ & $\begin{array}{c}\text { Natural } \\
\text { attraction }\end{array}$ & $\begin{array}{l}\text { Tourist attractions } \\
\text { mentioned in the online } \\
\text { travels that are smallly } \\
\text { influenced by humans } \\
\text { and formed entirely by } \\
\text { natural influences or }\end{array}$ \\
\hline
\end{tabular}

\begin{tabular}{|c|c|c|}
\hline & & $\begin{array}{l}\text { mainly by natural } \\
\text { influences. }\end{array}$ \\
\hline $\begin{array}{l}\text { bus, drip } \\
\text { taxi }\end{array}$ & $\begin{array}{l}\text { Tourist } \\
\text { traffic }\end{array}$ & $\begin{array}{l}\text { Tourists on the Internet } \\
\text { travel description and } \\
\text { evaluation of Guilin } \\
\text { traffic, city traffic, } \\
\text { traffic in the scenic area } \\
\text { and road conditions. }\end{array}$ \\
\hline $\begin{array}{c}\text { master } \\
\text { beer fish, } \\
\text { bamboo } \\
\text { rice }\end{array}$ & $\begin{array}{l}\text { special } \\
\text { dishes }\end{array}$ & $\begin{array}{l}\text { The description and } \\
\text { evaluation of the type of } \\
\text { food, the degree of } \\
\text { deliciousness and the } \\
\text { price of the destination } \\
\text { by the tourist in the } \\
\text { online travel. }\end{array}$ \\
\hline inn, room & $\begin{array}{l}\text { Accommoda } \\
\text { tion } \\
\text { conditions }\end{array}$ & $\begin{array}{l}\text { The network has several } \\
\text { types of tourists } \\
\text { describing and } \\
\text { evaluating destination } \\
\text { accommodation types, } \\
\text { housing prices, and the } \\
\text { environment. }\end{array}$ \\
\hline $\begin{array}{c}\text { per capita, } \\
\text { cheap }\end{array}$ & $\begin{array}{c}\text { Tourism } \\
\text { consumption }\end{array}$ & $\begin{array}{l}\text { The description and } \\
\text { evaluation of the price } \\
\text { level and tourism } \\
\text { consumption of tourists } \\
\text { in the online travel. }\end{array}$ \\
\hline $\begin{array}{l}\text { passionate } \\
\text { and kind }\end{array}$ & $\begin{array}{c}\text { Service } \\
\text { Level }\end{array}$ & $\begin{array}{l}\text { The description and } \\
\text { evaluation of the service } \\
\text { attitude, service skills } \\
\text { and service level of } \\
\text { tourists in the } \\
\text { destination travel } \\
\text { practitioners in online } \\
\text { travel. }\end{array}$ \\
\hline $\begin{array}{l}\text { unfamiliar } \\
\text {, nice }\end{array}$ & $\begin{array}{c}\text { Overall } \\
\text { impression }\end{array}$ & $\begin{array}{l}\text { The overall impression } \\
\text { of tourists on the travel } \\
\text { environment and tourist } \\
\text { atmosphere of the }\end{array}$ \\
\hline
\end{tabular}




\begin{tabular}{|l|l|l|}
\hline & $\begin{array}{l}\text { destination in the online } \\
\text { travel. }\end{array}$ \\
\hline
\end{tabular}

\subsection{Cognitive image}

Through the overall coding of high-frequency vocabulary and 200 travel notes, it is classified into eight categories: human attraction, natural attraction, tourism traffic, special food, accommodation conditions, overall impression, tourism consumption and service level.

In terms of human attraction, the Grand Falls Hotel has the highest frequency, with the solar and lunar towers ranked second; the East West Streets ranked third. In terms of natural attractions, Top of the list is elephant trunk mountain; In terms of tourism and transportation, external transportation is dominated by high-speed rail, while internal traffic is mainly bus and Drip taxis; In specialty food, Beer fish appear most frequently in travel notes, and in the choice of restaurants, the Chunji Roast Goose is the most popular; In terms of accommodation conditions, tourists are more likely to choose inns, homestays, etc. In the travel notes, tourists refer to the tourism consumption in Guilin, which is more likely to feel that it is cheap, affordable and the overall price is not high; As for service, tourists think that the hospitality of local residents is warm and cordial. Tourists feel strange at the beginning and feel good at the end. It is a gradual change.

\subsection{Emotional image}

Through the analysis of 100 travel texts, Tourists' overall evaluation of Guilin (table 3 ) is mainly dominated by positive emotions $(82 \%)$, while negative emotions only account for $3 \%$, Positive emotions are expressed in terms of natural tourism resources in Guilin. Negative evaluations are mainly reflected in the gap between tourists' expectations and reality, For example, Yangshuo West Street, Xingping Ancient Town, etc., tourists believe that these places are over-commercialized. Although retaining local architecture, the way of marketing has become too commercial, not with a local history. Excessive development makes visitors feel that they are not authentic..

Table 3.sentiment analysis of network text

\begin{tabular}{|c|c|c|}
\hline $\begin{array}{c}\text { Emotional } \\
\text { type }\end{array}$ & $\begin{array}{c}\text { Emotional } \\
\text { field }\end{array}$ & Percentage \\
\hline Positive emotion & 164 & $82 \%$ \\
\hline Neutral emotions & 30 & $15 \%$ \\
\hline Negative emotions & 6 & $3 \%$ \\
\hline
\end{tabular}

\subsection{Renewed willingness}

The travel notes include words such as " come again", "next time", "return", "again", which means that tourists have the willingness to revisit. Through the analysis of 200 travel samples, Of these, 66 did not explicitly indicate that they would visit Guilin again, and 134 did. It is clear that the proportion of willingness to revisit is high, indicating that tourists' overall satisfaction with Guilin is high, the desire and behavior trend of tourists to Guilin again is strong, and the word-to-word pass will affect the decision-making of potential tourists.

Table 4. Frequently updated frequency of visitors

\begin{tabular}{|c|c|}
\hline Revisiting intention & Frequency \\
\hline expressly revisit & 134 \\
\hline unrecognized & 66 \\
\hline
\end{tabular}

\section{3 conclusions and Suggestions}

\subsection{Conclusion}

Through the above analysis, the comprehensive perception of tourists' image of Guilin's tourist destination is summarized as follows: Tourists are generally satisfied with the natural attraction of the mountains, the beauty, the paradise of the world, and the human attraction, which is represented by the Lijiang River, Yangshuo, Elephant Trunk Hill Park and Gudong Forest Park. In addition to the historical human resources of Princess Jingjiang Residence being mentioned by tourists, tourists have vacated the perception of Guilin's historical and human resources; In terms of selecting tourist facilities and equipment, tourists will learn through the online platform in advance, and they will be affected by various factors such as the outside world and themselves. The mood of tourists during the journey is always "sorrowful and happy"; A large proportion of tourists have negative views on the bustling commercial atmosphere of Yangshuo County. Under the satisfaction of the overall image of Guilin, $66 \%$ of tourists have the willingness to revisit.

\subsection{Suggestions}

Guilin needs to pay attention to the following aspects in terms of infrastructure construction: First, the number of buses and buses should be increased in terms of transportation facilities; Secondly, some travel notes reflect the increase of the tour distance during the road maintenance process in Guilin, which results in extreme inconvenience, so the cycle of road repair should be shortened and a good traffic environment should be created for tourists; Finally, as the parking of battery cars affects the sidewalk, it is necessary for relevant departments to carry out standardized management, add parking lots or implement the lottery system for battery cars..

The characteristics of a city are not only composed of the natural environment of the city, but also closely related to the city's culture, history, art and other elements. For a 
tourist city, these elements are indispensable elements for promoting sustainable tourism development. Relevant departments and personnel need to transform cultural resources into tangible tourism resources, and tangible them into visually perceptible objects for display so that they can be perceived and disseminated. Therefore, the six elements of tourism should be integrated into the local culture of Guilin, so that tourists can feel the unique cultural symbols of Guilin everywhere, so as to deepen tourists' perception of Guilin cultural resources, which can not only improve tourists' perception of cultural resources, but also further explore and carry forward Guilin culture.

\section{Acknoledgments}

Thanks for the help of the fund: The National Science Foundation of China Funded Project: Investigation on the Pro-poor Tourism Effects and It's Influencing Mechanism on Settlement Space Evolution in Southwest Minority Villages. (No.41661031), Jan. 2017 - Dec. 2020.

\section{References}

1. Fakeye, P. C, Crompton, J. L. JOTA,30,10-16(1991)

2. Reeve,Rice,Fick.Content Analysis Method-Media information Quantification Research Skills (Media Management and Management Frontier Translation Clues,2010) 